\title{
Commentary
}

\section{The Quest for Representative Juries in the Northwest Territories}

\author{
Charles B. Davison*
}

Inherent in our constitutional right to a jury trial in criminal cases-for offences where imprisonment for five years or more is a possible sentence-is the right to have jurors who are our "peers" and "equals." This right can be traced back to 1215 when King John signed the Magna Carta to make peace with the wealthy men of England.

The route from the Magna Carta to Canadian criminal law in the early twenty-first century is long and convoluted, and extra twists and turns are added when we consider the use of juries in Canada's North. Here, where the effects of colonialism are still felt on a daily basis, and where communities from which a jury might be drawn sometimes number only a few hundred persons, the ability to obtain a jury comprised of "the peers" of our clients, who are usually Indigenous, can be challenging and sometimes difficult. In this article I offer my perspective, as a practising criminal defence lawyer in the Northwest Territories, on the challenges we face in trying to obtain juries that truly represent the communities from which our clients originate.

\section{The Meaning and Importance of "Representativeness"}

As originally enacted in the Magna Carta, the right to a jury of one's "equals" was intended to protect the rights of English nobles who were no longer willing to submit to the whims of the king or his hand-picked judges and other officials. As part of their agreement with King John, the nobles insisted on the right to have 
a jury composed of members of their class and social standing-their "equals"intercede in their court proceedings.

Much has changed in the centuries since the Magna Carta. Canada has evolved such that juries composed exclusively of White, English-speaking menfor most of our history the only possibility due to the laws defining eligibility for jury duty-can no longer be accepted as being truly representative of our communities and society. We have recently come to appreciate the value in having a jury that more accurately represents the multicultural, very diverse makeup of modern Canadian society.

A majority of judges in the Supreme Court of Canada have taken a fairly narrow view of what "representativeness" means in this context. In 2015 the Court said an accused is only entitled to jurors who are "honestly and fairly chosen" from a "representative cross-section of society." ${ }^{1}$ Representativeness, the Court said, "is about the process used to compile the jury roll, not [the] ultimate composition [of the jury itself]." In particular, accused persons are not entitled to a jury that includes members of their race or ethnic group, nor a jury that reflects the many ethnicities that make up modern Canada. ${ }^{2}$

Despite the Supreme Court's views, as a criminal defence lawyer I nonetheless seek to obtain a jury that does include in a more meaningful sense the "peers" of the individual I am assisting in court. While I certainly share the Supreme Court's interest to ensure the process by which we select juries is fair and inclusive, as a defence lawyer my concerns go further. When it comes to race or ethnicity, if I am defending a non-White person I want a jury that includes at least some other non-White members (whether or not they are actually of the same background as my client). When I am defending a First Nation, Métis, or Inuvialuit person, I want the jury to include as many other Indigenous persons as possible.

Part of the concern for actual representativeness on the jury may be considered somewhat "symbolic." When a minority-accused looks around the courtroom and sees only people who are apparently of the majority-usually "White" - there is more likely to be a suspicion, if not a real concern (whether or not it is valid and well-founded), that the decision may be made, or at least influenced, by resort to racial or ethnic biases and stereotypes. When such an accused can look at the jury box and see at least a few persons who appear to be of the same, or similar, origins and background, he or she can have greater confidence the influence of racial dynamics may be lessened, if not avoided altogether.

Furthermore, as jurors are told in every criminal trial, they represent the community and they are asked to bring that community's values to bear upon their decision-making process. These aspects of a jury's role are most meaningful if the jury actually represents the community in question. If a particular 
community is composed of two or more main racial groups, questions about true "representativeness" can be expected to arise if the jury is composed completely of persons apparently from only one of those sectors.

Thus, the ultimate verdict may be more willingly accepted if the accused and other members of the ethnic group to which he or she belongs see that the decision included the involvement of, and is supported by, other members of their ethnic group. As the well-known adage confirms, it is important that justice not only be done, but that it be seen to be done.

But the interest in having a truly representative jury is more than cosmetic. Virtually every jury is told by the trial judge that they should use and rely upon their own life experiences and "common sense" as they assess the evidence and come to their decisions. We now appreciate that the "life experiences" of members of minority groups in Canada often are very different from those of the majority population. One of the most prominent and important (but not the only) example in the context of criminal court proceedings is in the area of interactions between police and members of minority groups. As a number of Royal Commissions and inquiries have recently confirmed, ${ }^{3}$ relations between Canadian Indigenous persons and police officers (who are usually White; or at the very least, not fellow Indigenous citizens) are often plagued by suspicion and distrust, and sometimes even more negative experiences and histories.

This is where the value of having a diverse and representative jury is heightened. A jury composed only of members of the majority may instinctively sympathize with police officers (usually drawn from the same group) in any situation where there are questions or issues about their dealings with Indigenous persons. Members of the majority might view skeptically courtroom descriptions of or explanations for events that are not consistent with their own world views and life experiences. A "White" jury, for example, may not fully or properly understand - and may regard unfairly on the basis of stereotypes-why an Indigenous person (accused or witness) would run from the police, or not freely and willingly speak with the police, or not be completely open or truthful with the police during an interview. On the other hand, an Indigenous juror may be able to counter the views and assessments of the majority members of the group by explaining and discussing his or her own history of interactions with the police, which might play into the dynamics of any particular set of circumstances. It is in such situations that the value of the life experiences of diverse individual jurors become so important. 


\section{The Past: From "White" to "Representative" Juries}

As noted above, concerns for representativeness and diversity on juries are a relatively recent development in Canadian law. For many years the experience in Canada's North was to the opposite effect: First Nations accused were tried by exclusively White juries. By law, jurors had to be male, Canadian citizens or British subjects, and had to speak and understand English. Indigenous persons were not granted Canadian citizenship until 1956. Furthermore, the requirement for fluency in English effectively excluded most Indigenous persons living in isolated or remote areas where English was not used commonly, if at all.

At the same time, despite a clear lack of what we would now consider representativeness and diversity, it seemed there was at least sometimes an appreciation or sympathy for the situation of Indigenous persons even where the jurors were all White. Especially where Canadian law was first being extended and applied to communities and individuals who had been following local traditions and practices, juries at least occasionally seemed to show surprising understanding for the positions of the accused.

At first, northern accused were removed from their communities and sent south to stand trial in the large, White-populated centres such as Edmonton and Calgary. Perhaps the best known example is the 1917 prosecution of two Inuit men from the Kugluktuk area (then known as Coppermine). After receiving reports in 1913 that two White priests had been killed, the Royal North-West Mounted Police dispatched an officer who briefly investigated, arrested, and charged the two men, and then brought them over 1,500 kilometres south for a trial in Edmonton. Although the accused had nothing in common with the six White men selected as jurors, the jury apparently took account of what they had heard of the local customs and conditions and returned a verdict of not guilty. (Not content with this outcome, the prosecutor moved the matter to Calgary for a trial on a charge that had not been the subject of the Edmonton proceedings. This time the jury-again, all White men-dutifully found the men guilty but gave the "strongest possible recommendation" for mercy. $)^{4}$

A few years later, in 1923, the government sent a court party north to try an Inuk man for the murder of a White trader near Pond Inlet (Mittimatalik), in what is now Nunavut. By holding the trial in the area, the government intended to "educate" the local people as to the results if they offended against Whites and Canadian law. Consideration was given to having a jury of the "peers" of the accused, but this was not intended to include local Inuit; rather, the government wanted White northern residents who it hoped would be less sympathetic than had apparently been the case in the Kugluktuk proceedings. Ultimately, the six man jury was comprised of the (White) officers of the ship that had brought the court party to the area. ${ }^{5}$ 
Also in 1923, two Inuk men were tried on Herschel Island (Qikiqtaruk), off the northern coast of the Yukon Territory, for murders committed far to the east in what is now Nunavut. Even more than in the Pond Inlet (Mittimatalik) trial, the government wanted a show trial to send a brutal message about its response to murders committed by Inuit persons (shortly before he became involved, the government lawyer appointed to defend the accused had written that they should be publicly hanged to ensure all other Inuit would see the cost of taking human life!). Jurors were all White settlers living along the Mackenzie River, who were told by the judge (in what was then acceptable, but would now be considered shockingly offensive, racist language) that their task was to send a message to the Inuit that killing was against the law. As Whites living in an area populated by Indigenous people, the judge told the jurors they would ultimately "have to bear the consequences" of any verdict they rendered. The jury convicted and the two accused were hanged in early $1924 .^{6}$

From the 1920s until 1955 very few jury trials took place in the North. Before 1955, judges came to the Northwest Territories from southern Canada (usually the West) to hold court on an ad hoc basis, but that year Alberta lawyer John Sissons was named the first judge of the Territorial Court of the Northwest Territories. He quickly decided (despite the wishes of the government that appointed him) that instead of bringing accused persons to Yellowknife, the court itself would travel to the scattered communities in the territory (which at the time included what is now Nunavut) in order to "bring justice to the people." One of the reasons he insisted that trials be held as close as possible to where events had taken place was to enforce the rights of the accused to juries drawn from the local area. ${ }^{7}$

However, despite Justice Sissons's efforts to engage the local populace, due to the continuing language barriers it was not until 1966 that Inuit persons were permitted to serve on a jury, at the trial of two Inuit men in Spence Bay (now Taloyoak/Talurjuaq, Nunavut). ${ }^{8}$ After flying about 2,400 kilometres to a number of communities in the area, the sheriff returned with two Inuit men who had some knowledge of English, and they were then selected for the jury. ${ }^{9}$ (During deliberations it became clear that these two jurors did not completely grasp some of what had been discussed in English, but Justice Sissons accepted a defence argument that allowing an interpreter at that late stage might cause a mistrial. ${ }^{10}$ ) According to later comments by a juror, in coming to its decision (acquittal of one accused and a finding of manslaughter in relation to the other) the jury placed great emphasis upon local Inuit traditions and practices.

Defence counsel in the Spence Bay (Taloyoak/Talurjuaq) trial-William Morrow, who shortly afterward became Justice Sissons's successor on the benchsaw the outcome as a vindication of the process and noted that while a strict application of the law would have led a judge to convict, the jury had used its 
collective wisdom and good sense to bring in a "socially acceptable verdict or solution." 11 After sitting as the judge on a number of the trials that followed, in 1970 Morrow published "A Survey of Jury Verdicts in the Northwest Territories" and concluded that from 1955 until the date of his article "no all-white jury has ... convicted an Eskimo accused." 12 Of sixty-eight juries empanelled during that period, Indigenous persons were on twenty-seven and composed half or more of the jurors on six. There were two juries composed entirely of Indigenous persons. ${ }^{13}$ Especially relevant to a discussion about "representativeness," Morrow noted that "if any trend is discernable, all-white juries seem to show more leniency towards native accused, particularly where the case involves cultural and sociological features." ${ }^{14}$

A final aspect of relevant history dates back to the early days of the Charter of Rights and Freedoms. The juries mentioned above were all composed of six members, although the usual Anglo-Canadian tradition has long been to have twelve jurors. As the Canadian Northwest was settled, the White population was too scattered and sparse to be able to regularly gather twelve men to serve as jurors, so the Criminal Code permitted juries of six for this part of the country, including the Yukon Territory. ${ }^{15}$ As the area of the Northwest Territories shrank-mainly with the creation of the provinces of Alberta and Saskatchewan in 1905, and then the expansion of the Manitoba and Ontario boundaries to the sixtieth parallelthe Criminal Code section went unchanged. Once Indigenous persons started sitting as jurors, a benefit to the lower number (it being easier to find six qualified persons as opposed to twelve) was the ability to hold jury trials in relatively small communities where jurors would be mostly, if not completely, of the same background and ethnicity as the accused and witnesses. Judges recognized the value of having input from local jurors who would reflect, and rely upon, local values and mores in performing their role as "the conscience of the community." 16

With the enactment of the Charter's Section 15 "equality rights" in 1985, however, came challenges to the law providing that northern juries would have only six members. Ultimately, a judge struck down this provision on the basis that twelve member juries - the norm in the rest of Canada-would be more, and not less, likely to fully and properly represent all sectors of society, better "able to cope with a dominant personality among its members," and less likely to be influenced by intimidation or other "external pressures upon its members." ${ }^{17}$ Parliament later removed that section from the Criminal Code completely. 


\section{The Present: Location Matters}

In the almost fifty years since Justice Morrow published his survey, times and views have changed. The old ways of Indigenous societies - which figured prominently, it seems, in coming to some of the decisions mentioned above- have become a thing of the past. Canadian criminal law is now enforced uniformly across the country and there is far less room, or occasion, for consideration of traditional norms, mores, and customs. Against this general backdrop, however, for the reasons offered at the beginning of this article, there remains a need (indeed, it has perhaps heightened over the last five decades) for true "representativeness" on our criminal juries. In larger centres this can prove to be a challenge.

In the Northwest Territories as currently drawn, the overall population is roughly evenly split between Indigenous and non-Indigenous citizens. However, that "split" is not consistent across the territory: the non-Indigenous population is centred in Yellowknife (the territorial capital with approximately 20,000 people, ${ }^{18}$ $75 \%$ of whom are non-Indigenous), which means it is hardly surprising that a First Nation or Inuit person whose trial will take place in that city will likely end up with a mainly - if not completely-White (or at least, non-Indigenous) jury. Even where the panel (the larger group of 150 or 200, sometimes more, persons brought to court from which the twelve member jury is chosen) includes a few Aboriginal persons, a significant number of them (like all the other potential jurors) will usually ask to be excused from jury duty for various reasons. Usually at least half of the people brought to court for jury selection will ask the judge to be excused for reasons relating to health, travel arrangements, work or school obligations, child care needs, and any number of similar explanations for why they cannot take the time away from their usual daily lives to hear a trial.

Furthermore, family connections or friendships are always a disqualifying concern in the selection of jurors who must usually be excluded if they are related to or know the accused or any other interested or involved person (mainly victims and witnesses). Regardless of population size, in any community an Indigenous accused is of course more likely to have familial and social connections to other local Aboriginal or Inuit persons. In the result where the accused is Indigenous, Indigenous persons summonsed for jury duty are more likely to be excused due to knowledge of or connection to the person being tried. (Sometimes judges reduce the numbers of such persons being removed from the jury panel by adopting a "flexible" approach; for example, a mere blood connection might not be sufficient to excuse a possible juror where, upon inquiry, it turns out that despite their family relationship the juror and the accused do not actually know or socialize with one another.) 
At the opposite end of the spectrum from Yellowknife, are the very small communities (sometimes only 500 citizens or fewer) scattered around the territory. While in such places the jury panel would include a vast majority of Indigenous citizens, it is virtually impossible to obtain a jury in such locations due to the family connections and friendships between the persons involved in the trial (complainants, witnesses, and accused) and potential jurors. For the most part, the court does not even try to obtain juries in these small settlements and instead moves the matter to the nearest larger centre where there might be a hope of finding twelve impartial and unconnected persons to serve (sometimes, for various reasons, such cases are sent to Yellowknife for trial).

Those larger centres are Inuvik (the "hub" of the Beaufort Delta and Arctic communities in the Northwest Territories; about 3,500 persons, of whom about 1,200 are non-Indigenous); Norman Wells (the largest settlement in the Sahtu region; non-Indigenous persons make up about $60 \%$ of the population); Hay River (Xátåodehchee; the largest town in the South Slave region and almost a 50-50 split in population makeup); and Fort Smith (Thebacha; non-Indigenous persons are approximately $30 \%$ of the population). Where the trial is to be held in such a regional "hub" the ability to have a truly "local" jury that includes persons from the community where the charges originate are greatly reduced. For example, an accused from a small community in the Mackenzie Delta or on the Arctic coast will usually have his or her jury trial in Inuvik. While there is always a chance the jury might include someone from the same community, this will only be possible if that person happens to live in Inuvik. The government does not bring people from other communities into Inuvik in order that they might serve as jurors. The jurors will be people residing in Inuvik, which might include other Indigenous persons from other First Nations, Whites, and any of the many others who represent the multicultural mosaic of twenty-first-century Inuvik. In a larger sense, Canadian society will be represented, but there is unlikely to be anyone on the jury who is actually from the small community most directly involved and interested in the proceedings.

It remains possible to obtain locally representative juries in some of the larger Indigenous communities in the Northwest Territories. Juries have been selected over the past few years in the mainly Indigenous communities of Tuktoyaktuk (on the Arctic coast; population roughly 1,000); Fort Simpson (Eíidlı Kuee, in the Dehcho region; about 1,200); and in the Tłıchǫ community of Behchoko (about 100 kilometres west of Yellowknife; approximately 2,000). While juries in these communities will often include much higher numbers of local Indigenous persons, in these settings the jury will often include a disproportionately high number of non-Indigenous citizens as well (if it is even possible to find twelve persons 
who can serve). This arises from mainly economic factors that seem to afflict Indigenous members of small communities more than non-Indigenous. For the most part, the "White" and other non-Indigenous members of small communities are in town because they have steady employment that brings them to the location in question. Teachers, health care providers, territorial government workers, and even managers of the local Northern Store tend to be non-Indigenous "outsiders" who, if they are called for jury duty, can take time away from their workplaces and serve as required without jeopardizing their employment or income. On the other hand, finding work is often more challenging for many local Indigenous persons. Income- whether earned in the Western style economy or in the more traditional ways - tends to be more seasonal: a local person might be hired for a short-term position when a particular community event occurs, or may spend part of the year on the land, trapping or fishing, or engaged in a seasonal hunt. If a jury trial is scheduled to take place during the same period when a seasonal position or occupation is available, the Indigenous citizen summonsed for jury duty will often not be able to serve because they cannot afford to miss the employment opportunity while it exists.

\section{The Future: New Challenges and Difficulties}

Looking forward, except in locations where they form the majority, the future does not bode well for the interests and concerns of Indigenous accused persons, and their lawyers, to ensure their juries include persons from the same ethnic groups and communities. In the 2015 decision referred to earlier, the Supreme Court of Canada had the opportunity to reform Canadian law in a way that would have promoted and increased the frequency with which members of Indigenous communities might be selected for jury duty. Instead, as summarized above, it opted to narrowly define the concept of "representativeness," and to restrict its force to the method of gathering the larger pool of persons together from which the actual jury would be chosen. In a large centre such as Yellowknife, this means that as long as the government does not directly seek to exclude Indigenous persons from the jury panel, the requirements of the law will have been met. The fact that few Indigenous citizens are called for jury duty, and even fewer, if any, are actually selected, will provide no basis for a legal objection to the jury ultimately chosen.

But even more importantly, in June 2019 Parliament passed Bill C-75, ${ }^{19}$ a lengthy set of amendments to the Criminal Code, which includes the abolishment of what were called "peremptory challenges" used by lawyers in the course of choosing a jury. Peremptory challenges were the tool by which lawyers on each side were usually able to have a small influence and choice about who would sit on 
a jury. ${ }^{20}$ By advancing such a challenge, which did not require any justification or reason, each side had a limited number of chances to exclude specific persons from sitting on the jury. In the context of the present discussion, as a defence lawyer I could use my client's peremptory challenges, for example, in an effort to obtain at least some representation of my client's community or racial group on the jury. Especially in a large centre such as Yellowknife where most potential jurors will be White (or at least, not Indigenous), I could challenge potential jurors until such time as an Indigenous person was selected to become a juror for my Indigenous client's trial. To be clear, the system was not perfect: I might exhaust my challenges without being able to get an Indigenous person on the jury; but we at least had this chance. (Ironically, the government's motive for abolishing peremptory challenges was the public outcry after an apparently all-White Saskatchewan jury acquitted a White farmer in the prosecution for the death of an Indigenous man in 2016. Because it appeared that the defence lawyer had used his peremptory challenges to exclude any possibly-Indigenous person from the jury, the use of this mechanism was attacked by supporters of the deceased. The government listened and responded by eliminating these challenges completely). ${ }^{21}$

Now, no matter what the race, background, or community of origin of my criminally-accused client, he or she will be forced to simply accept the first twelve persons called for jury duty from the group assembled by the court. My Indigenous client facing trial in Yellowknife, for example, will simply have to hope that if the first twelve persons called are all White (or otherwise not Indigenous themselves), they nonetheless regard him or her fairly. There will be no chance to have someone in the room who might have more in common with the accused, and who might have a better appreciation for the accused's life experiences based upon their own.

\section{Notes}

1. R. v. Kokopenace, 2015 SCC 58 at para 39.

2. $\quad I b i d$ at paras 40 to 42 .

3. See, for example, Report of the Commission of Inquiry into Matters Relating to the Death of Neil Stonechild (Government of Saskatchewan, 2004), online: <http:// www.publications.gov.sk.ca/freelaw/Publications Centre/Justice/Stonechild/

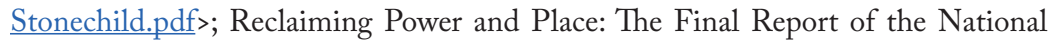
Inquiry into Murdered and Missing Indigenous Women and Girls (2019), online: $<$ https://www.mmiwg-ffada.ca/final-report/>; and for a more historical context, Final Report of the Truth and Reconciliation Commission of Canada (2015), online: $<$ http://www.trc.ca/about-us/trc-findings.html $>$. 
4. McKay Jenkins, Bloody Falls of the Coppermine: Madness and Murdern in the Arctic Barren Lands (Random House, 2006), is a detailed recounting of this case, not to be confused with Coppermine (Leckie) which is a romanticized novel based upon the same events. Each of the historical cases summarized here are themselves referred to and described in numerous other works, including the online version of the Canadian Encyclopedia, which has also been reviewed in the course of preparing this article. In the footnotes following, I cite only my primary source for each of the summaries.

5. Shelagh Grant, Arctic Justice: On Trial for Murder, Pond Inlet, 1923 (Montréal and Kingston: McGill-Queen's University Press, 2002).

6. Daniel Campbell, “An Arctic Kangaroo Court: The Spectacle of Canada's First Trial in the Far North Was Little More Than a Show of Force" (April 2015) Up Here, online: <https://uphere.ca/articles/arctic-kangaroo-court>; see also Graham Price, “The King v. Alikomiak" (1991) 20 Manitoba Law Journal 209.

7. Brian O.Bucknall, "John Howard Sissons and the Development of Law in Northern Canada" (1967) 5 Osgoode Hall Law Journal 159 at 160; and see the summary of this history in $R v$ Arnakallak, 2013 NUCJ 29 at paras 37 to 41 (though this is only one of many judicial references to Justice Sissons's decision to take the court to the communities; almost every review of this part of Justice Sissons's legacy makes the point that his approach was completely in keeping with the principles established in the Magna Carta). Interestingly, at the time Yellowknife was not the capital city (Fort Smith was the capital until Yellowknife was named capital in 1967) and yet Justice Sissons nonetheless made Yellowknife his main sitting point: see WG Morrow, “Arctic Circuit," The Beaver (Winter 1966), online: <https://canadashistory. partica.online/canadas-history/the-beaver-winter-1966/flipbook>.

8. Dorothy H Eber, Images of Justice: A Legal History of the Northwest Territories as Traced through the Yellowknife Courthouse Collection of Inuit Sculpture (Montreal, Kingston: McGill-Queen's University Press, 2008) at 144. In the Price essay cited (footnote 5 above) he says (at page 219) that a Dene juror sat on a trial in Fort Smith in 1947 and that the first Inuit juror was the foreman of a jury in Cambridge Bay in 1951, but he does not cite any sources for these details. I have not been able to find any confirmation of these points in any other records or writings.

9. J Vertes, Jury Trials - In Canadian Aboriginal Communities. A lecture delivered by former NWT Supreme Court Justice J Vertes as part of the "Law and Society" lecture series at the University of British Columbia Faculty of Law in January 2007. First published in 17(1) Commonwealth Judicial Journal (June, 2007).

10. Eber, supra note 8 at 146.

11. Ibid at 148 .

12. WG Morrow, "A Survey of Jury Verdicts in the Northwest Territories" (1970) 8 Alberta Law Review 50 at 51.

13. Ibid at 50 .

14. Ibid at 52 .

15. Section 561 of the Criminal Code, RSC 1985, c C-46. 
16. See, for example, comments quoted in $R v$ Fatt (1986) 30 CCC (3d) 69 at 72; 1986 CanLii 4741 (NWTSC).

17. $R$ v. Punch, 1985 CanLII 3533 (NWT SC), online: <http://canlii.ca/t/g93km >; see too the Court of Appeal decision in $R v$ Emile, 1988 CanLii 7055 (NWT CA), online: $<$ http://canlii.ca/t/g9vvr $>$.

18. All population figures are from Northwest Territories Bureau of Statistics: Community Population Estimates by Detailed Ethnicity, July 1, 2018, online: <https://www.statsnwt.ca/population/population-estimates/bycommunity.php>.

19. Now SC 2019, с 25.

20. The other means is by way of a more complicated "challenge for cause" process whereby potential jurors can be opposed for a number of reasons described in Section 638 of the Criminal Code. These include a lack of impartiality between the prosecution and the accused, but as presently interpreted and applied this provision requires the challenging party to show something close to "actual bias" before a potential juror will be excluded. This section would thus not provide a means by which the apparent racial and ethnic composition of the jury might otherwise be affected.

21. I am referring here to the prosecution of Gerald Stanley for the death of Clayton Boushie, which received significant media coverage as the trial took place in Battleford, Saskatchewan, in early 2018. Much has been written about the proceedings since the acquittal of Stanley. The Kent Roach book Canadian Justice, Indigenous Injustice (MQUP, 2019) discusses a number of areas of controversy surrounding the case, including the use of, and the resulting push to abolish, peremptory challenges (a move which Roach supported) even as he also wrote about the need for "local juries" to ensure representation of Aboriginal communities among jurors sitting at such trials.

\section{Author}

Charles B. Davison is a criminal defence lawyer employed by the Legal Aid Commission of the Northwest Territories in Yellowknife. The views and opinions expressed in this article are solely those of the author. 